\title{
Government information and roles of libraries and archives: Recent policy issues in Japan
}

\author{
Takashi Koga \\ National Institute of Informatics
}

\begin{abstract}
Government information is an important part of the "knowledge infrastructure" of a government's citizens, in the way such information provides a reliable knowledge base relating both to laws and to everyday life. In addition, government information forms part of the historical and cultural heritage and serves as a means of accountability for current and future generations, provided that this information is archived and that its long-term accessibility is ensured.

Recently, central and local governments in Japan have developed a variety of policies concerning government information, including: (1) development of e-government and (2) promotion of archival systems. This article reviews these policies and discusses the challenges faced by libraries and archives in Japan in maintaining government information as part of the nation's knowledge infrastructure.
\end{abstract}

\section{KEYWORDS}

government information, library, archive, e-government, information policy

\section{Introduction}

Every government creates and manages a significant body of information. When this information is shared with citizens, it becomes a useful part of the infrastructure of public knowledge, in addition to its usefulness to government officials. Specifically, government information provides citizens with a reliable base of knowledge concerning laws and matters pertaining to everyday life. Additionally, government information forms part of the historical and cultural heritage and serves as a means of accountability for current and future generations, provided that this information is archived and that its long-term accessibility is ensured.

In order to make the most of government information, however, "information intermediaries" must effectively connect citizens to government officials by managing and encouraging access to government

Received December 1, 2004; Revised January 28, 2005; Accepted January 31, 2005.

tkoga@nii.ac.jp information. Further, public libraries and archives can play the role of intermediaries for government information and contribute to the development of the knowledge infrastructure. Each public library or archive may manage different kinds of government information; however, they all share the role of providing public services relating to this information.

This article discusses the functions of government information in terms of the knowledge infrastructure and analyzes recent policy issues concerning government information, libraries, and archives in Japan. The policy analysis in this article focuses primarily on the government at the national level. This is due to restrictions of time and space; moreover, local governments in Japan tend to follow national policy, particularly in terms of information, despite the enactment of the Collective Decentralization Law of 1999, aimed at enhancing the independence of local governments in Japan.

This article supplements the author's previous article, "Access to Government Information in Japan[1] ," 
published in 2003. While the previous article dealt with several policy issues concerning access to government information in Japan through the spring of 2002, the present article discusses issues following that period, especially the recent policy trends seen in public archives.

\section{Government Information in the Knowledge Infrastructure}

2.1 Types of government information

In this article, "government information" is broadly defined as including government publications, government websites, and government records. Moreover, the "government" referred to herein includes a wide range of government entities, such as legislative, administrative, and judicial bodies.

Government information can be divided into two types: "published" and "non-published" information". Published information "includes information products that the government imparts on its own initiative or that it is required to release" pursuant to laws and/or regulations. [2] This type of government information includes government publications in print and government websites, both of which are created for public use. On the other hand, non-published information is primarily meant for use within the government and is not for public consumption. This type of government information includes government records or documents $^{2}$ that are not to be published. However, the term "non-published" information does not imply that the information is completely inaccessible to the public. For example, under "freedom of information" or "information disclosure" legislation in several countries, including Japan, government records are accessible to the public upon request by citizens. Moreover, government records are often made available to the public as historical documents for long-term storage in archives when such records are considered to be of historical importance.

The dichotomy between published and non-published information can be said to correspond to the dichotomy between "dissemination of information" and "access to information," respectively, in Circular No. A-130, "Management of Federal Information

\footnotetext{
1 The dichotomy of "published" and "non-published" information is based on, Hernon et al. [2], who employ the words "public" and "non-public" information. However, this article uses the former terminology because it appears more natural than the latter.

2 In this article, a "record" (kiroku in Japanese) implies a document created as an evidence of legal requirements and/or business activities, while a "document" (bunsho in Japanese) implies merely information material created along with business activities. In this sense, public archives collect and maintain government records, not government documents. This article mainly uses "records," though the word "documents" is also used when it appears in legislations and official reports and documents in Japan.
}

Resources," issued by the U.S. Office of Management and Budget. Appendix IV, added to the circular in 1993 [3], explains the distinction as follows (emphasis added):

- Dissemination of information: "actively distributing information to the public at the initiative of the agency."

- Access to information: "giving members of the public, at their request, information to which they are entitled by a law."

Although the above explanations are based on government information in the U.S., they could be applicable to any number of countries, including Japan. In any case, published and non-published information can be made accessible to citizens under the appropriate legislation and systems. In general, published information in tangible (i.e., paper) format can be made accessible in public (and other) libraries. On the other hand, non-published information not currently in use but of historical value can be made accessible in public archives, while non-published information in current use remains within the respective government bodies.

\subsection{Importance of government information}

Why should government information be made accessible to citizens as part of the knowledge infrastructure? This question may be answered based on four considerations: (1) the rule of law, (2) quality-oflife issues, (3) the historical and cultural heritage, and (4) accountability for current and future generations.

(1) The rule of law: In a democratic government, the sharing of government information among the government and citizens is considered essential in terms of the rule of law. Perritt [4] explains this issue: "The concept of a rule of law requires availability in advance of the rules according to which conduct will be judged... [P]ublished rules encourage compliance and reduce the burden on adjudicatory and enforcement institutions." According to Perritt, the rule of law requires the opening up not only of basic laws and statutes but also of other published information such as census information, geographical information, and land records, as a complete knowledge of these issues reassures business and everyday life under the jurisdiction of the government in question.

(2) Quality-of-life issues: Government information contributes to the quality of life of the citizens. For example, the provision of information regarding toxic materials, health care, education, and so forth, must be provided by the government rather than by non-governmental bodies. This is because non-governmental bodies may not be able to issue such information freely due to the limitations of market forces, which 
often result in information bias and call into question the fairness and equity of the content.

(3) Historical and cultural heritage: Government information includes reliable information about the community, ranging from geographic and demographic data to still and motion pictures that reflect the lives of citizens at that time. If such information is archived and its long-term accessibility is ensured, it functions as part of the historical and cultural heritage, contributes to community identity, and encourages non-community members to gain an understanding of the community.

(4) Accountability for current and future generations: Any government action is a continuous process; it is thus important for the government to maintain records of its actions in order to reproduce or improve them in the future. Without such records, it would be difficult for the government to act with the full consent of its citizens. Government information ensures this accountability insofar as it provides a record of the actions undertaken by the government. As in the case of information saved for the historical and cultural heritage, government information should be archived and its long-term accessibility should be secured as part of the public record to as a means to ensure governmental accountability.

The difference between published and non-published information is important in this context. Published information is provided at the initiative of the government, while the government may be reluctant to disclose non-published information, as this might conflict with the content of published information. Precisely for this reason, citizens may wish to investigate the governmental agenda through access to the non-published information. Disclosure of non-published information is an important part of such investigation.

In these ways, published and non-published government information both function as elements of the knowledge infrastructure available to citizens. However, in their roles as information intermediaries, public libraries and archives must facilitate the sharing of information among citizens and government officials. The relationship between government information and public libraries and archives in Japan will be discussed in the following section.

\section{A Glance at Legislation Concerning Government Information and Libraries and Archives in Japan}

This section presents an overview of current legislation concerning government information-both the published and non-published information discussed above, particularly in paper format-and intermediaries for that information, i.e., libraries and archives in Japan.

\subsection{Published information-government publications}

With regard to government publications, Japanese law mandates that national and public libraries stock these publications and ensure that library users have access to them.

First, the National Diet Library Law (Law No. 5 of 1948) [5] requires each entity within the central and local governments to send its publications to the National Diet Library of Japan for "legal deposit." Chapter X of the law, "Deposit of Publications Issued by Government and Local Public Entities," which consists of Article 24 and Article 24-2, states that government entities at both the national and local level should deposit their publications of various types, including books, maps, photographs, films, and electronic materials, in the National Diet Library. Here, "electronic materials" are defined as: "Texts, images, sounds, or programs recorded by electronic, magnetic, or other methods, which cannot be directly perceived by human senses" (Article 24). This definition was included when the National Diet Library Law was revised in 2000. However, this definition reflects an interpretation of electronic materials as tangible, thus excluding government websites and other types of networked information. This interpretation was based on the final report submitted by the Legal Deposit System Research Council, an advisory panel of outside experts, to the Librarian of the National Diet Library (NDL) in February 1999. This report stated: "Networked electronic publications should be excluded from the legal deposit system for the time being, and for those which are considered necessary or beneficial would be acquired by contract." [6]

In addition to the legal deposit in the National Diet Library, public libraries that are established and managed by local governments are subject to a similar deposit system for government publications. Article 9 of the Library Law (Law No. 118 of 1950) [7] allows national and local government entities to deposit their publications in public libraries; however, it is unclear whether "publications" in these articles include electronic materials.

However, the effectiveness of such legislation is questionable. In fact, several government publications 
have been conspicuously absent from the deposit system of national and local public libraries. For example, Aida [8] clarified that only $18 \%$ of bibliographical records in 1985 were duplicated between the Japanese National Bibliography, created by the National Diet Library of Japan based on its legal deposit system, and the bibliography of the Government Data Center of Japan, a major information center for government publications in Japan. Since that time, the extent to which the legal deposit system has included government publications that were previously excluded is unclear.

\subsection{Non-published information-government records}

\subsubsection{Information disclosure system}

One of the most important items of legislation regarding access to government records as non-published information is the Information Disclosure Law (IDL) [9]. Officially termed the "Law Concerning Access to Information Held by Administrative Organs" (Law No. 42 of 1999), it was enacted on May 7, 1999 and came into effect on April 1, 2001. The IDL provides procedures at the national level for the disclosure of "administrative documents" in current use, including those in electronic format.

Appropriate management of government records is a precondition for information disclosure. While the IDL urges national administrative entities to manage their documents properly under Article 37, "Management of Administrative Documents," the management of records in national administrative entities is curtailed by the lack of effective laws and guidelines, such as lack of an oversight system for records management within each entity. An editorial page concerning the National Archives in a Japanese newspaper renders a concise description of this problem: [10]

Administrative documents produced by government ministries and agencies are to be kept from one to 30 years. When such documents near their expiration date, a decision is to be made as to whether they are to be scrapped, transferred to the National Archives, or kept as they are for another period of time.

The major problem is that such decisions are currently, for all intents and purposes, left up to the ministries and agencies. ... They can extend the period for which they keep the documents, therefore maintaining control over them.

As a result, the ministries and agencies make little effort to manage the records that are in use, resulting in the problematic situation in which "precious documents are scattered and lost, intentionally scrapped or they gather dust in the ministries' lockers." [11]

In relation to access to published information, it is worth mentioning that Article 40 of the IDL,
"Enhancement of Measures for the Provision of Information Held by Administrative Organs," urges administrative agencies to provide their information to the public on a proactive basis. Although this Article does not specify concrete measures for such provision of information, it does function to promote the intent of making government information available-including through management of government websites, which will be discussed later in this article.

Several local governments in Japan established information disclosure ordinances before the enactment of the IDL at the national level. Beginning in 1982 in Kanayama Town in Yamagata Prefecture, these ordinances ensured access to local government records upon request. However, only a few local governments have included provisions concerning records management in their information disclosure ordinances, while almost all local governments have regulations concerning their own records management procedures. In other words, information disclosure and records management are not interlinked in a number of local governments.

\subsubsection{Archive systems}

In Japan, the management of government records for current use is governed by the Information Disclosure Act or by local ordinance. On the other hand, the management of national and local government records that are not in current use but are of historical importance is covered under the Public Archives Law and the National Archives Law.

The Public Archives Law (Law No. 115 of 1987) [12] issues provisions concerning the management of "official documents ... as historical materials" and public archives at the national and local level. This law also mandates that public archives hire "professional personnel" to perform investigations and research into such official documents under Article 4 of the law. However, Supplementary Provision 2 states: "For the time being, Public Archives to be established by local public entities may operate without appointing professional personnel..." Worse still, the law does not effectively encourage the establishment of public archives in local governments. Therefore, several local governments do not have archives due to financial constraints, although in recent years the number of local public archives has gradually risen.

Although the National Archives of Japan was established in 1971, the National Archives Law [13] was enacted quite recently, as Law No. 79 of 1999. The provisions of this law are similar to those of the Public Archives Law concerning the management of "official documents ... as historical materials." It also provides that the Prime Minister of Japan, and not the head of 
the National Archives, is in charge of transferring government documents of historical importance from each national government body to the National Archives.

The status of the National Archives is also problematic. While it was an organ of the Prime Minister's Office since its establishment in 1971, it became an independent administrative agency in 2001 as the result of overall administrative reform in the central government. This "reform" weakened the power and status of the National Archives: "all it could do was to convey its opinion to the Cabinet Office; it could no longer make direct requests for other government agencies' documents." [11] This resulted in a decline in the number of documents transferred from each government agency to the National Archives; "An average of 17,000 documents were transferred to the archive from other government agencies every year until fiscal 2000. But that number decreased to 7,759 in fiscal 2002, and to 5,764 in fiscal 2003.” [11]

\subsection{Summary of legislative measures}

Libraries and archives in Japan face the adverse affects of ineffective legislation concerning government information. A more serious problem, however, is that the various legislative measures discussed above were established when almost all government information was created, managed, and distributed in paper format. Currently, both national and local governments can provide information via the Internet; this situation demands that governments develop new policies addressing the management of government information in an electronic environment. Such policies are discussed in the following section.

\section{Recent Policy Issues in Japan}

\subsection{Development of e-governments}

In Japan as in other countries, the central and local governments are taking initial steps to establish what are referred to as "e-governments." Establishment of an e-government can be defined as the "use of technology, particularly Web-based Internet applications, to enhance the access to and delivery of government information and service to citizens, business partners, employees, other agencies, and entities." [14]

Since January 2001, the "e-Japan Strategy" has formed the primary driving force in the development of e-government as well as an in the general establishment of an information society in Japan. The IT Strategic Headquarters under the Prime Minister of Japan and his Cabinet pursues initiatives under the e-Japan strategy, and the Headquarters' website [15] provides overall information regarding this strategy. The e-Japan Strategy forms a strategic framework for the development of an information society in Japan, and it outlines the government's commitment to become "the world's most advanced IT nation" by 2005. The e-Japan Strategy consists of five core plans: (1) accelerated construction of the world's most advanced networks, (2) enhancement of IT human resource development, (3) facilitation of e-commerce, (4) digitization of the administration, or establishment of e-governments, and (5) ensuring the security and reliability of advanced information and telecommunications networks.

One of the recent action plans under the e-Japan Strategy, the "e-Japan Strategy II Acceleration Package" of February 2004 [16], includes a project for the "Establishment of Digital Archives of Government Content and Expansion of Its General Use." Under this action plan, the National Diet Library will assume the lead in establishing "Digital Archives of Government Content," i.e., "long-term storage of the Web sites of government agencies," though it is unclear whether these "Digital Archives" will cover web content both of central government entities and of local government entities. This project is reaffirmed in a later action plan, the "e-Japan Priority Policy Program-2004" of July 2004, as a project to be implemented in fiscal 2004 [17].

In addition to the e-Japan Strategy, the Administrative Management Bureau (AMB) of the Ministry of Internal Affairs and Communications has assumed the lead in the promotion of government information provision over the web. The most important initiative concerning government website management at the national level is the "Basic Plan for Electronic Provision of Administrative Information." [18] This basic plan was approved on March 29, 2001, by the Inter-ministerial Council for Promoting Government-wide Use of Information Technology led by the AMB, and was revised on July 30, 2002 by the council. The plan categorizes the objects of electronic provision into four types of administrative information: (1) information regarding administrative activities; (2) information for effective use in society, including administrative information databases; (3) information regarding the laws and regulations that mandate provision; and (4) information that will be frequently requested through IDL procedures. This basic plan also indicates standardized categories under which each ministry and agency at the national level will provide its information over the web, including white paper content, conference and research reports, legislative information, and so forth. The standardized categories are listed in Table 1.

Based on these initiatives, government bodies in Japan are developing a number of e-government interfaces. The core interface is e-Gov.go.jp, or the General 
Table 1: Standardized Categories of Information to be Provided through Japanese Government Websites

\begin{tabular}{|c|c|c|c|}
\hline $\begin{array}{l}\text { Classification } \\
\text { of } \\
\text { information }\end{array}$ & $\begin{array}{l}\text { Category of } \\
\text { information }\end{array}$ & Example of content & $\begin{array}{l}\text { Retention period } \\
\text { for information } \\
\text { provision on the } \\
\text { web }\end{array}$ \\
\hline \multirow{10}{*}{$\begin{array}{l}\text { Basic } \\
\text { information } \\
\text { regarding } \\
\text { administrative } \\
\text { organization } \\
\text { and system }\end{array}$} & \multirow{5}{*}{$\begin{array}{l}\text { Brief description } \\
\text { of organization } \\
\text { and institution }\end{array}$} & Brief description of administrative activities & \multirow{5}{*}{ N/A } \\
\hline & & Internal organizations and their activities & \\
\hline & & Directory of senior management staff & \\
\hline & & Directions to the offices & \\
\hline & & $\begin{array}{l}\text { Information regarding extra-governmental organizations and public } \\
\text { corporations }\end{array}$ & \\
\hline & \multirow{5}{*}{$\begin{array}{l}\text { Laws, } \\
\text { notifications, } \\
\text { instructions, } \\
\text { circulars }\end{array}$} & Text and summaries of bills and related explanatory information & \multirow{5}{*}{$\begin{array}{l}\text { For the text of new } \\
\text { and revised laws- } \\
\text { until such time as } \\
\text { other government } \\
\text { databases provide the } \\
\text { same text }\end{array}$} \\
\hline & & Text and summaries of new laws and related explanatory information & \\
\hline & & $\begin{array}{l}\text { Text and summaries of revised laws and related explanatory } \\
\text { information }\end{array}$ & \\
\hline & & Full text of the laws of the concerned ministry & \\
\hline & & $\begin{array}{l}\text { Full text of notices and circulars of the concerned ministry and other } \\
\text { information concerning citizens' and corporations' activities }\end{array}$ & \\
\hline \multirow{13}{*}{$\begin{array}{l}\text { Information } \\
\text { on current } \\
\text { status of } \\
\text { administrative } \\
\text { activities }\end{array}$} & \multirow{3}{*}{$\begin{array}{l}\text { Master plans, } \\
\text { projects, etc. }\end{array}$} & Full text or summary of master plans, projects, etc. & \multirow{3}{*}{$\begin{array}{l}\text { Until the end or } \\
\text { revision of the master } \\
\text { plans, projects, etc. }\end{array}$} \\
\hline & & Their current status & \\
\hline & & Their results and costs & \\
\hline & Results of research & Summary; reports; related materials & Three years \\
\hline & \multirow{3}{*}{$\begin{array}{l}\text { Materials of } \\
\text { deliberativecouncils }\end{array}$} & Full text and summary of reports & \multirow{3}{*}{ Three years } \\
\hline & & Summary or full text of the minutes & \\
\hline & & Full text or parts of the related materials & \\
\hline & Public comments & & N/A \\
\hline & $\begin{array}{l}\text { Summary of white } \\
\text { papers }\end{array}$ & & Three years \\
\hline & $\begin{array}{l}\text { Briefing and } \\
\text { summary of } \\
\text { statistical research } \\
\end{array}$ & & $\begin{array}{l}\text { Until the publication } \\
\text { of new research }\end{array}$ \\
\hline & \multirow{2}{*}{$\begin{array}{l}\text { Procedures and } \\
\text { forms }\end{array}$} & Summary of the procedures and forms & \multirow{2}{*}{ N/A } \\
\hline & & Instructions for the procedures and forms & \\
\hline & $\begin{array}{l}\text { Procurement } \\
\text { information }\end{array}$ & & N/A \\
\hline $\begin{array}{l}\text { Budget and } \\
\text { account } \\
\text { settlement } \\
\text { information }\end{array}$ & $\begin{array}{l}\text { Summary of the } \\
\text { budget and account } \\
\text { settlement }\end{array}$ & & Three years \\
\hline $\begin{array}{l}\text { Evaluation } \\
\text { information }\end{array}$ & $\begin{array}{l}\text { Results of the } \\
\text { evaluation }\end{array}$ & Summary and full text of the results of the policy evaluation and audit & Three years \\
\hline \multirow{2}{*}{$\begin{array}{l}\text { Common to } \\
\text { above } \\
\text { classification }\end{array}$} & Press releases & & Six months \\
\hline & $\begin{array}{l}\text { Information } \\
\text { disclosure }\end{array}$ & Register of administrative documents & $N / A$ \\
\hline
\end{tabular}

Source: "Basic Plan for Electronic Provision of Administrative Information" [18] and Suzuki [32]. Italics show additions pursuant to revision of the plan in 2002. Tentative interpretation by the author. 
Gateway System for Electronic Government [19]. The e-Gov.go.jp was launched on April 1, 2001, on the day that the IDL came into effect and it is a portal, or "one-stop," source of administrative information and services in Japan. Other important e-government interfaces include:

- Legislative Data Dissemination System (Japanese only) [20]

- The Portal Site of Statistical Data in Japan [21]

- Retrieval System for the National Diet Minutes (Japanese only) [22]

Several local governments have also created e-government interfaces providing information concerning residential life, governmental ordinances and regulations, PR information for tourists, and so on. Some local governments provide information in foreign languages, including English, Chinese, Korean, Portuguese, and more.

These e-government initiatives have facilitated the provision of government information as published information on the web within a short span of time. However, these programs rarely focus on non-published information, i.e., on government records to be created and managed by e-governments. The issue concerning non-published information is treated through another initiative concerning archival systems, which are discussed below.

\subsection{Promotion of archival systems}

With regard to the management of non-published government information in Japan, the most important policy initiative in recent years concerns the discussions and activities of advisory bodies under the Cabinet Office, as listed below:

- The Blue-Ribbon Commission on Improving and Consolidating Public Archival Systems (May 2003-Nov. 2003) [23]

- The Panel Advising Chief Cabinet Secretary on Reviewing a System for Management, Preservation, and Use of Archives and Records of the Government (Dec. 2003-June 2004) [24]

The establishment of the above advisory bodies is an epoch-making event in terms of archival communities in Japan, in that:

- The top-level management body of the Japanese government is now aware of the importance of managing and archiving government records.

- The Chief Cabinet Secretary, Yasuo Fukuda ${ }^{3}$ assumed the leadership of the committees: twenty years ago, he was shocked when he found old photographs of his hometown, which were not included in any archive collections in Japan, in the U.S. National Archives ${ }^{4}$. This experience urged him to establish the Blue-Ribbon
Commission.

- Masaya Takayama, Professor at Keio University and one of the leading scholars of library science and records management in Japan, serves as Chair of the Blue-Ribbon Commission and the Panel. In Japan, it is rare for a researcher in such a field to assume leadership of any research committee, especially one concerning general issues, sponsored by a national government body.

The Blue-Ribbon Commission was established in April 2003 based "on the recognition that government documents and records of importance as historical materials are public property and that preserving them in a systematic manner, making them available to the public, and bequeathing them to future generations are important tasks." The objective of these committees was "to deliberate measures for improving, expanding and strengthening systems related to public archives in Japan, including the National Archives of Japan, an independent administrative institution, while taking into consideration advanced efforts and related activities in this field in other countries." [25]

In the fall of 2003, members of the Blue-Ribbon Commission conducted field research at the national archives in China, Korea, the USA, and Canada for a report to the council concerning "advanced efforts and related activities in this field in other countries." The research topics included:

- General issues of each national archive

- Records acquired at the archives

- Management of current records

- Preservation of semi-current records

- Transfer of records to the archives

- Disclosure and use of archival records

- Training of professional archivists

- Unique activities of each country

In December 2003, the former Blue-Ribbon Commission published its research report concerning the above topics [26], and was converted to the higherlevel Panel in terms of members (a leading scholar of administrative law joined the Panel) and status (the former ad hoc commission becoming a panel under the direct supervision of the Chief Cabinet Secretary). In addition, this new Panel expanded its scope from that of the former Commission; the Panel discussed the management not only of non-current government records but also of those in current use.

On January 19, 2004, just a month after the new Panel was organized, Prime Minister Jun'ichiro

\footnotetext{
3 Fukuda resigned as Chief Cabinet Secretary in May 2004 because of a scandal concerning a pension funds system.

4 This situation is reflected in the final report of the Panel, stating: "If the people want to see the record of postwar Japan, they had better visit the National Archives in the United States." [11]
} 
Koizumi reaffirmed the policy of strengthening the management and archival system of government records, in his General Policy Speech to the Diet: [27]

We will strive to develop the system for appropriate preservation and use of documents at national archives so that records of the government's activities and historical facts can be passed on to future generations.

In addition to its relevance to the activities of advisory bodies under the Cabinet Office, this statement was of particular interest to various archival communities, as it was the first time that a Prime Minister of Japan had mentioned an issue of records management and archives in a General Policy Speech.

On June 28, 2004, the panel submitted its final report to the Chief Cabinet Secretary, Hiroyuki Hosoda, entitled "Keeping Historical Records into the Future: Challenges for the Development and Consolidation of Japanese Archives." [28] The panel was dissolved after the submission of its final report. This report includes several policy recommendations, such as measures to transfer documents from each government body to the National Archives, education and staffing of archivists and record managers within each government body and archive, management of electronic records, and so forth.

Archival communities and journalists in Japan have applauded this report for its reaffirmation of the importance of the archival system and records management in government activities, as well as for its proposal of several measures to improve records management and the archival system. In particular, the proposal put forth in the report to establish a record center, in which "important administrative documents can be temporarily placed under integrated management," [10] has met wide approval. On the other hand, the report has been criticized in its hesitation to discuss in detail new legislation concerning records management and archival systems for both paper and electronic records.

Since the submission of the panel's final report, the editorial pages of several national and local newspapers have demanded reform of the Japanese archival system. For example, the Daily Yomiuri's editorial page [10] reaffirms the importance of records management and archival systems for the government, saying: "governments are obliged to preserve documents on the making of important decisions for use as a record to explain how the government works to people in the future." The editorial also demands that the government shift "the status of the National Archives from that of an independent administrative institution back into that of an organization affiliated with the Cabinet Office, and giv[e] it greater authority," in order to realize the ideas discussed in the Panel and to improve general records management and archival systems in Japan. The Asahi Shimbun's editorial page [11] also makes a similar argument.

Based on the recommendations of the Panel, it is anticipated that the Cabinet Office, the National Archives, and other national government bodies will rapidly develop policy initiatives concerning the management of government records and archives.

\section{Challenges and Roles of Libraries and Archives}

This section discusses the challenges facing, and the optimal roles of, libraries and archives under the above-mentioned initiatives for managing and providing government information in an electronic environment.

\subsection{Preservation of government information}

One of the most important and challenging roles of libraries and archives is to preserve content, regardless of whether the information in question is published or non-published, and to ensure the long-term accessibility of this content to the public. By carrying out this responsibility of preservation, the government will ensure its accountability to present and future citizens based on the archived government information. The government can also develop the historical and cultural heritage by preserving government information. Electronic information in particular, however, is at a risk of deletion -whether by accident or by the intent of the respective government bodies. To prevent this, libraries and archives must develop technological as well as social (e.g., copyright and privacy) solutions.

However, e-government initiatives in Japan have not completely considered the preservation and archive system for published and non-published information; they have merely stressed the importance of information "flow" and have ignored information "stock." As discussed earlier, the plan of the "Establishment of Digital Archives of Government Content and Expansion of Its General Use" represents a new trend in the e-Japan Strategy. Prior to the plan, since 2002 the National Diet Library has conducted the pilot Web Archiving Project (WARP) for archiving national and local government websites as well as selected popular e-journals. However, this project has dealt only with a very small portion of these websites. Legislation must be developed to address the archiving of government websites within the framework of the deposit system in national and local public libraries. As discussed earlier, government websites and other networked types of information are excluded from the legal deposit system in the National Diet Library. The advisory panel of the National Diet Library is currently considering a 
new archiving procedures for government websites as well as for other non-government networked information.

Moreover, it is possible for libraries and archives to digitize paper-based government information for purposes of preservation as well as for public access. The Japan Center for Asian Historical Records (JACAR), a branch of the National Archives of Japan, is currently engaged in such activity, providing access to digitized government records, particularly diplomacy-related records since the Meiji era. JACAR's website [29] allows users to retrieve and browse the JACAR collections using both English and Japanese interfaces, along with explanations in languages such as Chinese [30] and Korean [31].

\subsection{Developing service points}

The preservation of content is meaningless without use and associated service. As discussed at the beginning of this article, each public library and archive may manage a different type of government information; however, they all share a public service role with respect to this information. Therefore, it is important for libraries and archives to develop the service points that will provide electronic government information.

In terms of library services that make use of government websites, it is important that the libraries identify the types of information that are available on the web and to develop a "virtual" service point or a portal grouping government websites, and if necessary, one that sorts related non-government information by subjects for users and communities. In terms of archives, the abovementioned JACAR example provides a good illustration of a virtual service point.

In addition to virtual service points, libraries in particular need to develop "real" service points. These would consist of PC terminals to provide government and non-government information for public use, as well as librarians knowledgeable in government activities as well as in the use of the PC and the Internet.

\subsection{Evaluation of government information}

It is also important for libraries in particular to evaluate government information from the standpoint of the users of that information.

For libraries, the evaluation of government websites can be observed as an extension their evaluations of books. A library has the responsibility of evaluating the quality of the information resources it offers, from books to CDs to websites, in order to develop its collections (in terms of tangible resources) and service portals (in terms of non-tangible resources). However, the evaluation of government websites should include policy criteria covering items such as the treatment of personal records and the adoption of universal design, as well as ease-of-use criteria, such as site-navigation convenience and removal of dead links.

In Japan, Suzuki [32] investigated the extent of information provision of each national government body on the web, and arrived at the following conclusions:

- Overall, government bodies improved the provision frequency and usability of information through their websites.

- However, information provision is not exhaustive; in particular, research reports and council proceedings tend to be subject to delays before being made available to the public.

- Moreover, the organization of content poses several problems. For example, there is a lack of uniformity in certain title words of web documents and reports. This may cause problems in information retrieval.

As observed from Suzuki's evaluation, libraries must continually evaluate government websites at the macro level (i.e., in terms of overall provision) as well as on the micro level (i.e., in terms of each site).

\subsection{Expanding roles and scope}

Finally, the roles of libraries and archives need to be extended beyond traditional expectations and should incorporate the creation and management of government information. Libraries and archives should be involved at an earlier stage in the management of government information, especially in an electronic environment, instead of merely being recipients of government information from government agencies.

For example, archives should be considered in the development of management system of electronic records. Otherwise, the transfer of electronic records from each government agency to the archives will be quite difficult, as electronic records are much more at risk of deletion and falsification, whether by accident or by the intention of the ministries and agencies, compared with the case of records in the paper format. The "Guidelines for Managing Electronic Records from an Archival Perspective," by the International Council on Archives, [33] stress the importance of actively considering archival issues in the development of a records management system at the earliest stage:

[A]n archive whose activities start only when records are transferred will confront numerous technical difficulties. Many of these difficulties could be eliminated or avoided if the archives could influence the records creators earlier in the life cycle [of the records].

The Hokkaido Prefecture in Japan has implemented a general system for the management of prefecture records, with the involvement of the Hokkaido 
Prefecture Archives. [34]

In addition, libraries may also become involved in developing policies to add metadata to government websites and in overseeing the implementation of these policies. Metadata will enable libraries to identify titles, characteristics, and functions of government Websites, and will general facilitate website retrieval. Several states in the United States maintain metadata systems for their government websites, under the leadership of the state library and archive communities. [35]

\section{Conclusion}

While government information becomes more available on the web, it becomes more useful not only for the citizens of that government but also for people throughout the world. At the same time, such information is increasingly exposed to a number of risks, including deletion and falsification. Libraries and archives can contribute to ensuring access to government information and to developing the knowledge infrastructure -both for the benefit of citizens as well as that of government officials- through their roles as information intermediaries. To realize these roles, libraries and archives need to take into consideration the characteristics and shortcomings of current policy concerning government information, and to become involved in the process of policy development.

The Japanese government is working to use the Internet to its advantage to formulate its information policies in a manner that will satisfy the needs of the citizens in an electronic environment. However, in reality, the government first needs to overcome several challenges in order to facilitate access to government information. It is also imperative that libraries and archives in Japan realize their roles as information intermediaries at the policy stage.

\section{Acknowledgement}

This article is the revised version of a paper presented at the 2nd Shanghai International Library Forum in Shanghai, China, on October 12-15, 2004.

\section{References}

[1] T. Koga, "Access to Government Information in Japan: A Long Way toward Electronic Government?," Governm. Inform. Quart., vol. 20, no. 1, pp. 47-62, 2003.

[2] P. Hernon, J. A. Shuler, and R. E. Dugan, U.S. Government on the Web: Getting the Information You Need, 3rd ed., Libraries Unlimited, Westport, 2003. ISBN: 1-59158-086-2.

[3] "Management of Federal Information Resources," Federal Register, vol. 58, no. 126, pp. 36068-36086, 1993.

[4] H. H. Perritt, "Open Government," Governm. Inform. Quart., vol. 14, no. 4, pp. 397-406, 1997.

[5] National Diet Library Law, National Diet Library of Japan. http://www.ndl.go.jp/en/aboutus/laws.html, accessed Oct. 31, 2004.

[6] Legal Deposit System Council, National Diet Library of Japan. http://www.ndl.go.jp/en/aboutus/ deposit_council_book.html, accessed Oct. 31, 2004.

[7] Library Law, Japan Library Association. http://www.jla.or.jp/law-e.html, accessed Oct. 31, 2004.

[8] N. Aida, "Waga Kuni ni Okeru Gyousei Siryou Ryuutsuu no Jittai [The Distribution of Government Publications in Japan: A Comparative Research of Bibliographies]," Joho no Kagaku to Gijyutsu [J. Inform. Sci. Technol. Assoc.], vol. 39, no. 10, pp. 411-419, 1989. (in Japanese)

[9] Information Disclosure Law, Administrative Management Bureau, Ministry of Internal Affairsand Communications. http://www.soumu.go.jp/gyoukan/ kanri/translation3.htm, accessed Oct. 31, 2004.

[10] "Editorial: Public records are lifeblood of democracy," The Daily Yomiuri, p. 4, July 20, 2004.

[11] "Editorials: Role of National Archives: An upgrade is needed for information disclosure," The International Herald Tribune the Asahi Shimbun, p. 27, Aug. 20, 2004.

[12] Public Archives Law, National Archives of Japan. http://www.archives.go.jp/en/law/public.html, accessed Oct. 31, 2004.

[13] National Archives Law, National Archives of Japan. http://www.archives.go.jp/en/law/national.html, accessed Oct. 31, 2004.

[14] D. McClure, Electronic Government: Challenges Must Be Addressed with Effective Leadership and Management, U.S. General Accounting Office (GAO01-959T), Washington, 2001 . http:// www.gao.gov/cgi-bin/getrpt?GAO-01-959T, accessed 
Oct. 31, 2004.

[15] IT Strategic Headquarters, Prime Minister of Japan and His Cabinet. http://www.kantei.go.jp/foreign/policy/it/ index_e.html, accessed Oct. 31, 2004.

[16] e-Japan Strategy II Acceleration Package, IT Strategic Headquarters, Prime Minister of Japan and His Cabinet, 2004. http://www.kantei.go.jp/foreign/policy/ it/040318senryaku_e.pdf, accessed Oct. 31, 2004.

[17] e-Japan Priority Policy Program 2004: Summary, IT Strategic Headquarters, Prime Minister of Japan and His Cabinet, 2004. http://www.kantei.go.jp/foreign/ policy/it/040615summary/040615gaiyo_e.pdf, accessed Oct. 31, 2004. (Only a summary of this program is available online in English.)

[18] Gyuosei Jouhou no Denshiteki Teikyou ni kansuru Kihonteki Kangaekata (Shishin) [Basic Plan for Electronic Provision of Administrative Information (Revised)], Inter-ministerial Council for Promoting Government-wide Use of Information Technology, 2002. http://www.soumu.go.jp/s-news/2002/020730_4. html, accessed Oct.31, 2004. (in Japanese)

[19] e-Gov.go.jp, Administrative Management Bureau, Ministry of Internal Affairs and Communications. http://www.e-gov.go.jp/, accessed Oct. 31, 2004. (Only the "web-search" function is available in English.)

[20] Hourei Deta Teikyou Shisutemu [Legislative Data Dissemination System], Administrative Management Bureau, Ministry of Internal Affairsand Communications. http://law.e-gov.go.jp/cgibin/idxsearch.cgi, accessed Oct. 31, 2004. (in Japanese)

[21] The Portal Site of Statistical Data in Japan, Statistics Bureau, Ministry of Internal Affairs and Communications. http://portal.stat.go.jp/PubStat/ topE.html, accessed Oct. 31, 2004.

[22] Kokkai Kaigiroku Kensaku Shisutemu [Retrieval System for the National Diet Minutes], National Diet Library of Japan. http://kokkai.ndl.go.jp/, accessed Oct. 31, 2004. (in Japanese)

[23] Rekishi Shiryou to shite Jyuиyou na Koubunsho-tou no Tekisetsu na Hozon, Riyou no tameno Kenkyuukai [The Blue-Ribbon Commission on Improving and Consolidating Public Archival Systems]. http:// www8.cao.go.jp/chosei/koubun/kenkyukai/index.html, accessed Oct. 31, 2004. (in Japanese)

[24] Koubunsho-tou no Tekisetsu na Kanri, Hozon oyobi Riyou ni kansuru Kondankai [The Panel Advising Chief Cabinet Secretary on Reviewing a System for Management], Preservation, and Use of Archives and Records of the Government. http://www8.cao.go.jp/ chosei/koubun/index_k.html, accessed Oct. 31, 2004. (in Japanese)

[25] M. Kikuchi, "Blue-Ribbon Commission Established in the Cabinet Office of Japan to Improve and Consolidate Public Archival Systems," EASTICA Newsletter, no. 2, p. 1, 2003. http://www.eastica.org/
Publication/doc/newsletter2003.pdf, accessed Oct. 31, 2004.

[26] Shogaikoku ni okeru Koubunsho-tou no Kanri, Hozon, Riyuo-tou ni kakaru Jittai Chousa Houkokusyo [Research Report on Public Archival Systems in Foreign Countries], Blue-Ribbon Commission on Improving and Consolidating Public Archival Systems, 2003. http://www8.cao.go.jp/chosei/koubun/ kenkyukai/tyousahoukoku/031218.html, accessed Oct. 31, 2004. (in Japanese)

[27] General Policy Speech by Prime Minister Junichiro Koizumi to the 159th Session of the Diet, Jan. 19, 2004. http://www.kantei.go.jp/foreign/koizumispeech/2004/ 01/19sisei_e.html, accessed Oct. 31, 2004.

[28] Koubunsho-tou no Tekisetsu na Kanri, Hozon oyobi Riyou no tameno Taisei Seibi ni tsuite: Mirai ni Nokosu Rekishiteki Bunsho, Aakaibuzuno Jyuujitsu ni Mukete [Keeping Historical Records into the Future: Challenges for the Development and Consolidation of Japanese Archives (The Final Report of the Panel Advising Chief Cabinet Secretary on Reviewing a System for Management, Preservation, and Use of Archives and Records of the Government)], 2004. http://www8.cao.go.jp/chosei/koubun/kondankai08/ houkoku.pdf, accessed Oct. 31, 2004. (in Japanese)

[29] Japan Center for Asian Historical Records, National Archives of Japan, http://www.jacar.go.jp/index_e.htm, accessed Oct. 31, 2004.

[30] http://www.jacar.go.jp/f_c.htm, accessed Oct. 31, 2004. (in Chinese)

[31] http://www.jacar.go.jp/f_k.htm, accessed Oct. 31, 2004. (in Korean)

[32] M. Suzuki, "Gyousei Jouhou no Web Kontentsu-ka [Japanese Government Information Availability on the Web]," Joho Kanri [J. Inf. Process. Manage.], vol. 45, no. 8, pp. 534-543, 2002. (in Japanese)

[33] "3.1 The Life Cycle of Electronic Records," Guidelines for Managing Electronic Records from an Archival Perspective, Committee on Electronic Records, International Council on Archives, 1997. http:// www.ica.org/biblio/cer/guide_13.html\#310, accessed Oct. 31, 2004.

[34] H. Aoyama, "Hokkaido-ritsu Bunsyokan ni okeru Hokkaido Sougou Bunsyo Kanri Shisutemu no Dounyuu ni tsuite [The Report on the Information Control System in Hokkaido Archives]," Hokkaidoritsu Bunsyokan Kenkyu Kiyo [Bulletin of the Archives of Hokkaido], no. 18, pp. 77-132, 2003. (in Japanese)

[35] W. E. Moen, ed., "Special Issue-Metadata: A Networked Information Strategy to Improve Access to and Management of Government Information," Governm. Inform. Quart., vol. 18, no. 3, pp. 155-221, 2001. 


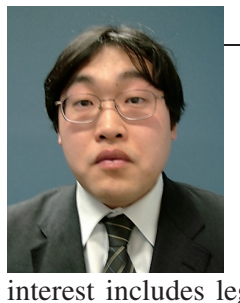

Takashi KOGA

Takashi Koga is an Assistant Professor at the National Institute of Informatics. He received B.A. in Law and M.A. in Education from the University of Tokyo, and Master of Library Science from Syracuse University, USA. Koga's research interest includes legal, institutional and policy researches concerning access to government information, and theoretical foundation of library and information science and records management. He has received the Young Author Best Paper Award from the Japan Society of Library and Information Science in 2001 and from the Records Management Society of Japan in 2002. 